\title{
PENGEMBANGAN MEDIA PEMBELAJARAN POBAR (POHON BANGUN RUANG) PADA MATERI BANGUN RUANG SISI DATAR
}

\section{DEVELOPMENT OF LEARNING MEDIA POBAR (POHON BANGUN RUANG) ON FLAT SIDE SPACE BUILDING MATERIAL}

\author{
A. Sriyanti ${ }^{1}$, Andi Halimah ${ }^{2}$, Nurfiana ${ }^{3}$ \\ 1,2,3 Fakultas Tarbiyah dan Keguruan UIN Alauddin Makassar \\ ${ }^{1,2,3}$ Kampus II: Jalan H.M. Yasin Limpo Nomor 36, Samata-Gowa \\ Email: a.sriyanti@uin-alauddin.ac.id ${ }^{1}$, andi.halimah@uin-alauddin.ac.id ${ }^{2}$, \\ nurfiananurfy@gmail.com ${ }^{3}$
}

\begin{abstract}
Abstrak
Penelitian ini bertujuan untuk mengembangkan media pembelajaran matematika pohon bangun ruang pada materi bangun ruang sisi datar yang valid, praktis, dan efektif. Jenis penelitian yang digunakan adalah penelitian research \& development dengan mengacu pada model ADDIE. Subjek uji coba pada penelitian ini adalah siswa kelas VIII $_{\mathrm{A}}$ MTs Ash-Shalihin. Produk yang dihasilkan adalah media pembelajaran berupa alat peraga matematika. Instrumen yang digunakan dalam penelitian ini adalah lembar validasi, lembar pengamatan pengelolaan pembelajaran, lembar aktivitas siswa, lembar angket respons guru dan siswa, serta tes hasil belajar. Berdasarkan hasil uji coba, diperoleh bahwa: (1) hasil validasi media pembelajaran adalah 3,40 berada pada kategori valid dengan interval 2,5 $\leq M \leq 3,5$, (2) praktis diperoleh berdasarkan respons guru dan respons siswa terhadap media pembelajaran sebesar 97,7\% dan 96,8\%, dan (3) efektif berdasarkan kemampuan guru dalam mengelola pembelajaran diperoleh rata-rata 3,91 berada pada kategori sangat baik dengan interval 3,5 $\leq K G \leq 4,5$, aktivitas siswa dalam kategori sangat baik yakni 96,8\% dengan interval persentase $80 \leq P \leq 100$, dan tes hasil belajar berada dalam kategori tinggi dengan persentase ketuntasan belajar keseluruhan siswa sebesar 86,3\%. Sehingga, dapat disimpulkan bahwa pada tahap uji coba, media pembelajaran pohon bangun ruang pada materi bangun ruang sisi datar kelas VIII MTs Ash-Shalihin telah memenuhi kriteria valid, praktis, dan efektif.
\end{abstract}

Kata Kunci: Pengembangan Media Pembelajaran, Pohon Bangun Ruang, Bangun Ruang Sisi Datar

\begin{abstract}
This study aimed to develop mathematics learning media of POBAR in flat, solid, practical, and effective material. The study used research and development with ADDIE models, namely analysis, design, development, implementation, and evaluation suggested by Steven J McGriff. The test subjects in this study were the students of class VIII A at MTs Ash-Shalihin. The instruments used in this study were validation sheets, learning management observation sheets, students' activity sheets, teachers' and students' response questionnaire sheets, and learning achievement tests. Based on the result of testing conducted, it was found that: (1) the results of the validation of learning media were 3.40 in the valid category because of the interval value $2.5 \leq M \leq 3.5$, (2) practical use obtained based on teachers' and students' responses to learning media was $97.7 \%$ and $98.8 \%$, and (3) the effectiveness based on the teachers' ability to manage learning was 3.91 in very good category with the intervals of $3.5 \leq K G \leq$ 4.5, the students' activity was $96.8 \%$ which was categorized in excellent with the interval value $80 \leq P \leq$ 100 , and the learning achievement test was in the high category and the overall learning completeness was $86.3 \%$. It could be concluded that, based on the testing stage, the implementation of POBAR learning media in flat side material of class VIII at MTs Ash-Shalihin fulfilled the valid, practical, and effective criteria.
\end{abstract}

Keywords: Development of Learning Media, Space-Building Trees, Build Flat Side Space 
How to Cite: Sriyanti, A., Halimah, A., \& Nurfiana. (2019). Pengembangan Media Pembelajaran POBAR (Pohon Bangun Ruang) pada Materi Bangun Ruang Sisi Datar. AULADUNA: Jurnal Pendidikan Dasar Islam, 6(2), 115-129.

\section{Pendahuluan}

Pendidikan memiliki peranan yang sangat penting dalam meningkatkan kualitas sumber daya manusia. Undang-undang sistem pendidikan nasional menunjukkan peran strategis pendidikan dalam pembentukan sumber daya manusia yang berkualitas. Karakter manusia Indonesia yang diharapkan menurut undang-undang tersebut adalah manusia yang beriman dan bertakwa, berbudi pekerti luhur, berkepribadian, maju, cerdas, kreatif, terampil, disiplin, profesional, bertanggung jawab, produktif, dan sehat jasmani dan rohani. Upaya efektif untuk membentuk karakter manusia seperti ini dapat dilakukan melalui peningkatan kualitas pendidikan (Kiswanto, Rahman, \& Sulasteri, 2015: 42). Pendidikan merupakan suatu keharusan. Hal ini dikarenakan pendidikan dapat memberi kemampuan dan kepribadian yang berkembang (Zaerani, Mardhiah, \& Suharti, 2017: 280).

Manusia dapat memperluas wawasannya dan memperoleh ilmu pengetahuan melalui pendidikan. Kualitas sumber daya manusia sangat menentukan kemajuan suatu bangsa. Kualitas sumber daya manusia sangat bergantung pada kualitas pendidikan dan peran pendidikan dalam masyarakat, sehingga akan membentuk komunitas yang cerdas, bersemangat, aktif, berperan dalam pengembangan ekonomi nasional, dan demokratis (Sari \& Setiawan, 2018: 101). Guru memberikan ilmu pengetahuan dalam proses pembelajaran sebagai bekal siswa dalam menyelesaikan permasalahan dalam kehidupan. Matematika merupakan ilmu pengetahuan yang sangat penting untuk dipelajari (Suharjana, 2008: 15). Matematika merupakan induk dari semua pengetahuan. Hampir semua mata pelajaran menggunakan perhitungan matematika, seperti fisika, kimia, dan akuntansi. Masyarakat sering berhubungan dengan perhitungan dan angkaangka dalam dunia teknologi maupun kehidupan sehari-hari. Hampir semua hal di dunia ini menggunakan ilmu matematika (Masykur \& Syazali, 2017: 178).

Banyak permasalahan yang harus diselesaikan untuk mewujudkan pendidikan matematika yang baik. Seperti permasalahan dalam proses kegiatan pembelajaran. Salah satunya adalah penggunaan media pembelajaran. Penggunaan media pembelajaran yang kurang menarik bisa menyebabkan proses pembelajaran terkesan monoton dan membosankan, karena pada dasarnya semua orang menghendaki keadaan hidup yang menyenangkan. Salah satu kondisi yang menyenangkan adalah adanya variasi dalam kehidupan. Demikian juga dalam proses pembelajaran, bila guru tidak berusaha mengadakan variasi dalam mengajar, maka siswa mudah bosan, perhatian siswa akan berkurang, mengantuk, dan tidak termotivasi mengetahui materi yang disampaikan guru, sehingga tujuan pembelajaran tidak tercapai (Muzakkir, 2012: 165). Sehingga, guru diharapkan mampu memilih media pembelajaran yang dapat mengatasi masalah tersebut, guna mencapai tujuan pembelajaran.

Berdasarkan hasil observasi dan wawancara kepada guru mata pelajaran matematika sekaligus wali kelas VIII diperoleh bahwa model pembelajaran yang digunakan adalah model pembelajaran langsung, dalam artian proses pembelajaran lebih berpusat pada guru, yang mengakibatkan interaksi di antara siswa masih kurang. Media pembelajaran yang digunakan juga terkesan monoton karena hanya menggunakan media pembelajaran berupa buku paket serta kerangka kubus dan balok yang terbuat dari karton manila. Media pembelajaran tersebut kurang memberikan waktu yang cukup 
kepada siswa untuk memahami materi-materi yang dipresentasikan, menghubungkannya dengan pengetahuan sebelumnya, dan mengaplikasikannya ke dunia nyata. Apalagi jika hal ini dikaitkan dengan materi geometri terkhusus bangun ruang sisi datar. Meskipun geometri diajarkan, namun kenyataan di lapangan menunjukkan bahwa materi tentang bangun ruang sisi datar kurang dikuasai oleh sebagian besar siswa. Hal ini dibuktikan ketika guru mengajukan beberapa pertanyaan terkait materi bangun ruang sisi datar, dari 26 siswa yang mengikuti proses pembelajaran, hanya terdapat 3 siswa yang mengacungkan tangan untuk menjawab pertanyaan tersebut dan jawaban mereka masih keliru. Siswa masih bingung membedakan sifat-sifat dari bangun ruang sisi datar, seperti jumlah rusuk, sisi, titik sudut, diagonal bidang, dan diagonal ruang pada kubus, balok, prisma, dan limas.

Beberapa upaya pernah dilakukan untuk mengatasi permasalahan yang terjadi, di antaranya adalah membimbing siswa dalam mengerjakan soal. Namun, kelemahannya adalah tidak semua siswa dapat dibimbing karena karakteristik siswa yang berbeda dan jumlah mereka yang cukup banyak. Mengenai hal tersebut, perlu adanya perbaikan metode, pendekatan, ataupun media yang diterapkan dalam pembelajaran (Gunantara, Suarjana, \& Riastini, 2014: 4). Hasil penelitian Nurfadillah (2017: 52) telah menunjukkan bahwa sebuah media pembelajaran berupa permainan ular tangga memperoleh nilai kevalidan media sebesar 3,60 berada pada kategori sangat valid, kepraktisan media berjumlah 4,11 berada dalam kategori tinggi, dan media dikategorikan efektif karena mencapai ketuntasan belajar sebesar 93,33\%. Selain itu, hasil penelitian Pratiwi, Riyana, \& Dewi (2013: 78) terkait media pembelajaran berbantuan komputer pada materi bangun ruang sisi datar kelas VIII menggunakan Augmented Reality Pocket Book (ARPOOK) juga mendapatkan penilaian yang sangat baik dari ahli media. Penilaian guru matematika pada dua aspek mendapat penilaian baik, penilaian teman sejawat pada dua aspek mendapat penilaian baik, dan respons siswa pada tiga aspek mendapatkan respons setuju.

Berdasarkan penjelasan di atas, media pembelajaran yang akan dikembangkan dalam penelitian ini berupa alat peraga pohon bangun ruang. Pemilihan media pembelajaran berupa alat peraga tersebut dikarenakan kondisi ruang kelas yang tidak memungkinkan untuk menggunakan media pembelajaran berbantuan komputer. Alat peraga pohon bangun ruang tersebut merupakan pengembangan dari media sebelumnya yang telah dimodifikasi semenarik mungkin. Harapan dikembangkannya alat peraga pohon bangun ruang ini yaitu mampu menambah daya tarik siswa dalam belajar matematika dan mampu membuat siswa memahami dengan mudah konsep awal dari suatu materi pada pelajaran matematika, khususnya pada materi bangun ruang sisi datar.

Jadi, dalam membentuk pola pengajaran matematika kepada siswa, guru hendaknya tidak semata-mata menilai hanya pada ketepatan dan kecepatan siswa dalam menyelesaikan soal. Namun, yang lebih penting adalah bagaimana proses siswa dalam menyelesaikan soal tersebut dengan mandiri, bebas, dan sesuai pola pikir mereka, serta bagaimana cara mengajak siswa untuk mampu memecahkan masalah dari soal yang diberikan dengan kemampuannya sendiri dan menerapkan cara yang kreatif untuk memahami, mengerti, dan menguasai konsep-konsep yang ada secara baik dan benar, sehingga siswa tidak lagi mengalami kesulitan dalam belajar (Arikunto, 1996: 67). 


\section{Metode Penelitian}

Jenis penelitian yang digunakan adalah Research \& Development (R\&D) atau penelitian pengembangan. Penelitian ini bertujuan untuk menghasilkan produk tertentu dan menguji keefektifan produk tersebut. Sesuai dengan definisinya, penelitian pengembangan adalah suatu proses atau langkah-langkah untuk mengembangkan dan menghasilkan suatu produk baru atau memodifikasi produk yang telah ada sebelumnya (Arsyad, 2015: 51).

Penelitian dan pengembangan adalah rangkaian proses atau langkah-langkah dalam rangka mengembangkan suatu produk baru atau menyempurnakan suatu produk yang telah ada agar dapat dipertanggungjawabkan (Trianto, 2007: 206).

Penelitian ini menggunakan model pengembangan ADDIE yang mengacu pada pendapat Steven J McGriff. Menurut Lee \& Owens dalam Puji, Gulö, \& Ibrahim (2014: 60 ), model pengembangan ini menunjukkan langkah yang jelas dan cermat untuk menghasilkan produk, karena prosedur kerja model ADDIE sangat sistematik yakni pada setiap langkah yang akan dilalui selalu mengacu pada langkah sebelumnya yang sudah diperbaiki sehingga diperoleh produk yang efektif. Model ini terdiri dari lima tahap, antara lain: analisis (analysis), perancangan (design), pengembangan (development), implementasi (implementation), dan evaluasi (evaluation).

Subjek uji coba dalam penelitian ini adalah siswa kelas VIII A MTs Ash-Shalihin. Instrumen pengumpulan data yang digunakan dalam penelitian ini adalah lembar validasi, lembar pengamatan pengelolaan pembelajaran, lembar aktivitas siswa, lembar angket respons guru, lembar angket respons siswa, dan tes hasil belajar.

\section{Hasil Penelitian dan Pembahasan}

\subsection{Hasil}

Hasil kevalidan media pembelajaran dapat diketahui dari hasil penilaian terhadap media pembelajaran pohon bangun ruang pada materi bangun ruang sisi datar yang diberikan oleh kedua validator pada tabel berikut.

Tabel 1. Hasil Uji Validasi Media Pembelajaran

\begin{tabular}{|c|c|c|c|c|}
\hline \multirow[t]{2}{*}{ Aspek yang Dinilai } & \multicolumn{2}{|c|}{$\begin{array}{l}\text { Nilai dari } \\
\text { Validator }\end{array}$} & \multirow[t]{2}{*}{ Rata-rata } & \multirow[t]{2}{*}{ Keterangan } \\
\hline & 1 & 2 & & \\
\hline \multicolumn{5}{|l|}{ Aspek Tampilan } \\
\hline $\begin{array}{l}\text { 1. Media pembelajaran memiliki } \\
\text { tampilan yang menarik }\end{array}$ & 3 & 4 & 3,5 & Sangat valid \\
\hline 2. Tata letak tiap media teratur & 4 & 4 & 4 & Sangat valid \\
\hline $\begin{array}{l}\text { 3. Komposisi media yang } \\
\text { ditampilkan sesuai pada } \\
\text { tempatnya }\end{array}$ & 3 & 4 & 3,5 & Sangat valid \\
\hline $\begin{array}{l}\text { 4. Komponen-komponen dalam } \\
\text { media pembelajaran sesuai } \\
\text { dengan tujuan pembelajaran }\end{array}$ & 3 & 4 & 3,5 & Sangat valid \\
\hline $\begin{array}{l}\text { 5. Media yang ditampilkan tidak } \\
\text { monoton }\end{array}$ & 3 & 3 & 3 & Valid \\
\hline 6. Kontras warna media bagus & 3 & 4 & 3,5 & Sangat valid \\
\hline 7. Media tidak mudah rusak & 3 & 4 & 3,5 & Sangat valid \\
\hline
\end{tabular}




\begin{tabular}{|c|c|c|c|c|}
\hline \multirow[t]{2}{*}{ Aspek yang Dinilai } & \multicolumn{2}{|c|}{$\begin{array}{l}\text { Nilai dari } \\
\text { Validator }\end{array}$} & \multirow[t]{2}{*}{ Rata-rata } & \multirow[t]{2}{*}{ Keterangan } \\
\hline & 1 & 2 & & \\
\hline 8. Ukuran media memadai & 3 & 3 & 3 & Valid \\
\hline $\begin{array}{l}\text { 9. Mudah terlihat oleh semua } \\
\text { siswa dalam ruangan kelas }\end{array}$ & 3 & 4 & 3,5 & Sangat valid \\
\hline 10. Mudah digunakan oleh siswa & 3 & 3 & 3 & Valid \\
\hline \multicolumn{5}{|l|}{ Aspek Bahasa } \\
\hline $\begin{array}{l}\text { 1. Bahasa yang digunakan mudah } \\
\text { dimengerti }\end{array}$ & 3 & 4 & 3,5 & Sangat valid \\
\hline Rata-Rata Total & & & 3,40 & Valid \\
\hline
\end{tabular}

Berdasarkan tabel 1, dapat diketahui bahwa rata-rata penilaian atau hasil validasi dari para ahli menyatakan bahwa rata-rata aspek media pembelajaran pohon bangun ruang pada materi bangun ruang sisi datar adalah 3,40. Hal ini berarti bahwa hasil penilaian dari kedua validator valid dengan kategori validitas berada pada interval $2,5 \leq$ $M \leq 3,5$.

Kepraktisan media pembelajaran diperoleh dari hasil analisis angket respons guru dan angket respons siswa terhadap media pembelajaran setelah melalui tahap implementasi di lapangan. Hasil analisis respons guru terhadap media pembelajaran pohon bangun ruang ditampilkan pada tabel berikut.

Tabel 2. Hasil Analisis Respons Guru terhadap Media Pembelajaran

\begin{tabular}{|c|c|c|c|c|c|c|c|c|c|}
\hline \multirow{2}{*}{ No } & \multirow{2}{*}{ Aspek Penilaian } & \multicolumn{4}{|c|}{ Skala } & \multirow{2}{*}{$\begin{array}{l}\text { Jumlah } \\
\text { Skor }\end{array}$} & \multirow{2}{*}{$\begin{array}{l}\text { Skor } \\
\text { Total }\end{array}$} & \multirow{2}{*}{ Persentase } & \multirow{2}{*}{ Ket. } \\
\hline & & 1 & 2 & 3 & 4 & & & & \\
\hline \multicolumn{10}{|c|}{ Aspek Materi } \\
\hline 1. & $\begin{array}{l}\text { Media sesuai dengan } \\
\text { tujuan pembelajaran }\end{array}$ & & & & $\sqrt{ }$ & 4 & 4 & $100 \%$ & Positif \\
\hline 2. & $\begin{array}{l}\text { Kedalaman materi } \\
\text { sesuai dengan } \\
\text { kemampuan siswa }\end{array}$ & & & $\sqrt{ }$ & & 3 & 4 & $75 \%$ & Positif \\
\hline 3. & $\begin{array}{l}\text { Media yang } \\
\text { ditampilkan tepat untuk } \\
\text { mendukung tujuan } \\
\text { pembelajaran }\end{array}$ & & & & $\sqrt{ }$ & 4 & 4 & $100 \%$ & Positif \\
\hline \multicolumn{10}{|c|}{ Aspek Penggunaan } \\
\hline 1. & $\begin{array}{l}\text { Media ini mudah } \\
\text { digunakan }\end{array}$ & & & & $\sqrt{ }$ & 4 & 4 & $100 \%$ & Positif \\
\hline 2. & $\begin{array}{l}\text { Media ini dapat } \\
\text { digunakan tanpa } \\
\text { keterampilan khusus }\end{array}$ & & & & $\sqrt{ }$ & 4 & 4 & $100 \%$ & Positif \\
\hline 3. & $\begin{array}{l}\text { Media ini sederhana } \\
\text { sehingga dapat } \\
\text { digunakan dengan } \\
\text { fasilitas seadanya }\end{array}$ & & & & $\sqrt{ }$ & 4 & 4 & $100 \%$ & Positif \\
\hline 4. & $\begin{array}{l}\text { Ukuran media memadai } \\
\text { untuk digunakan oleh }\end{array}$ & & & & $\sqrt{ }$ & 4 & 4 & $100 \%$ & Positif \\
\hline
\end{tabular}




\begin{tabular}{|c|c|c|c|c|c|c|c|c|c|}
\hline \multirow{2}{*}{ No } & \multirow{2}{*}{ Aspek Penilaian } & \multicolumn{4}{|c|}{ Skala } & \multirow{2}{*}{$\begin{array}{l}\text { Jumlah } \\
\text { Skor }\end{array}$} & \multirow{2}{*}{$\begin{array}{l}\text { Skor } \\
\text { Total }\end{array}$} & \multirow{2}{*}{ Persentase } & \multirow{2}{*}{ Ket. } \\
\hline & & 1 & 2 & 3 & 4 & & & & \\
\hline & $\begin{array}{l}\text { semua siswa dalam } \\
\text { ruang kelas }\end{array}$ & & & & & & & & \\
\hline 5. & $\begin{array}{l}\text { Media ini cocok } \\
\text { digunakan oleh } \\
\text { kelompok besar }\end{array}$ & & & & $\sqrt{ }$ & 4 & 4 & $100 \%$ & Positif \\
\hline 6. & $\begin{array}{l}\text { Media tidak mudah } \\
\text { rusak }\end{array}$ & & & & & 4 & 4 & $100 \%$ & Positif \\
\hline \multicolumn{10}{|c|}{ Aspek Motivasi } \\
\hline 1. & $\begin{array}{l}\text { Media ini dapat } \\
\text { membuat siswa lebih } \\
\text { aktif dalam } \\
\text { pembelajaran }\end{array}$ & & & & $\sqrt{ }$ & 4 & 4 & $100 \%$ & Positif \\
\hline 2. & $\begin{array}{l}\text { Media dapat menarik } \\
\text { minat siswa untuk } \\
\text { belajar }\end{array}$ & & & & $\sqrt{ }$ & 4 & 4 & $100 \%$ & Positif \\
\hline \multicolumn{8}{|c|}{ Rata-Rata Keseluruhan $=\frac{\text { Jumlah keseluruhan presentase }}{\text { Keseluruhan aspek }}$} & $97,7 \%$ & Positif \\
\hline
\end{tabular}

Berdasarkan tabel 2, dapat diketahui bahwa persentase rata-rata respons guru terhadap media pembelajaran pohon bangun ruang memiliki nilai lebih besar dari $50 \%$. Dari keseluruhan aspek yang ditanyakan, persentase respons guru adalah $97.7 \%$, sehingga dapat disimpulkan bahwa respons guru terhadap media pembelajaran pohon bangun ruang yang digunakan bernilai positif.

Hasil analisis respons siswa terhadap media pembelajaran pohon bangun ruang dapat diketahui pada tabel berikut.

Tabel 3. Hasil Analisis Respons Siswa terhadap Media Pembelajaran

\begin{tabular}{|c|c|c|c|c|c|c|c|c|c|}
\hline \multirow{2}{*}{ No } & \multirow{2}{*}{ Aspek Penilaian } & \multicolumn{4}{|c|}{ Skala } & \multirow{2}{*}{$\begin{array}{c}\text { Jumlah } \\
\text { Skor }\end{array}$} & \multirow{2}{*}{$\begin{array}{l}\text { Skor } \\
\text { Total }\end{array}$} & \multirow{2}{*}{ Persentase } & \multirow{2}{*}{ Ket. } \\
\hline & & 1 & 2 & 3 & 4 & & & & \\
\hline 1. & $\begin{array}{l}\text { Saya mendapatkan } \\
\text { pengetahuan yang lebih } \\
\text { mendalam tentang } \\
\text { materi bangun ruang } \\
\text { dengan bantuan media } \\
\text { pembelajaran tersebut. }\end{array}$ & 0 & 0 & 1 & 21 & 87 & 88 & $98,8 \%$ & Positif \\
\hline 2. & $\begin{array}{l}\text { Saya lebih mudah } \\
\text { memahami materi } \\
\text { bangun ruang dengan } \\
\text { bantuan media } \\
\text { pembelajaran tersebut. }\end{array}$ & 0 & 0 & 3 & 19 & 85 & 88 & $96,5 \%$ & Positif \\
\hline 3. & $\begin{array}{l}\text { Saya tertarik belajar } \\
\text { bangun ruang dengan } \\
\text { bantuan media } \\
\text { pembelajaran tersebut. }\end{array}$ & 0 & 0 & 2 & 20 & 86 & 88 & $97,7 \%$ & Positif \\
\hline 4. & Saya mudah & 0 & 0 & 1 & 21 & 87 & 88 & $98,8 \%$ & Positif \\
\hline
\end{tabular}




\begin{tabular}{|c|c|c|c|c|c|c|c|c|c|}
\hline \multirow{2}{*}{ No } & \multirow{2}{*}{ Aspek Penilaian } & \multicolumn{4}{|c|}{ Skala } & \multirow{2}{*}{$\begin{array}{c}\text { Jumlah } \\
\text { Skor }\end{array}$} & \multirow{2}{*}{$\begin{array}{l}\text { Skor } \\
\text { Total } \\
\end{array}$} & \multirow{2}{*}{ Persentase } & \multirow{2}{*}{ Ket. } \\
\hline & & 1 & 2 & 3 & 4 & & & & \\
\hline & $\begin{array}{l}\text { menggunakan media } \\
\text { pembelajaran tersebut } \\
\text { karena petunjuk } \\
\text { pemakaiannya jelas. }\end{array}$ & & & & & & & & \\
\hline 5. & $\begin{array}{l}\text { Saya menyukai } \\
\text { keserasian warna dan } \\
\text { tulisan pada media } \\
\text { pembelajaran tersebut. }\end{array}$ & 0 & 0 & 1 & 21 & 87 & 88 & $98,8 \%$ & Positif \\
\hline 6. & $\begin{array}{l}\text { Saya tidak kesulitan } \\
\text { melihat dan } \\
\text { menggunakan media } \\
\text { pembelajaran tersebut } \\
\text { karena ukurannya cukup } \\
\text { besar. }\end{array}$ & 0 & 1 & 1 & 20 & 85 & 88 & $96,5 \%$ & Positif \\
\hline 7. & $\begin{array}{l}\text { Saya bisa membaca } \\
\text { tulisan pada media } \\
\text { pembelajaran tersebut } \\
\text { dengan jelas. }\end{array}$ & 0 & 1 & 1 & 20 & 85 & 88 & $96,5 \%$ & Positif \\
\hline 8. & $\begin{array}{l}\text { Saya termotivasi } \\
\text { mengikuti proses } \\
\text { pembelajaran dengan } \\
\text { menggunakan media } \\
\text { pembelajaran tersebut. }\end{array}$ & 0 & 0 & 3 & 19 & 85 & 88 & $96,5 \%$ & Positif \\
\hline 9. & $\begin{array}{l}\text { Saya lebih aktif dalam } \\
\text { belajar bangun ruang } \\
\text { dengan menggunakan } \\
\text { media pembelajaran } \\
\text { tersebut. }\end{array}$ & 0 & 0 & 0 & 22 & 88 & 88 & $100 \%$ & Positif \\
\hline 10. & $\begin{array}{l}\text { Saya mudah berinteraksi } \\
\text { dengan teman } \\
\text { sekelompok saya dalam } \\
\text { menggunakan media } \\
\text { pembelajaran tersebut }\end{array}$ & 0 & 0 & 5 & 17 & 83 & 88 & $94,3 \%$ & Positif \\
\hline 11. & $\begin{array}{l}\text { Saya tidak merasa malu } \\
\text { berinteraksi kepada } \\
\text { siswa lain dalam } \\
\text { menggunakan media } \\
\text { pembelajaran tersebut. }\end{array}$ & 1 & 1 & 3 & 17 & 80 & 88 & $90,9 \%$ & Positif \\
\hline & Rata-Rata Keseluruhan & & $\frac{2 l a h}{K}$ & $\frac{\text { ese }}{\text { eselt }}$ & $\frac{\text { uruh }}{\text { ruha }}$ & $\begin{array}{l}\text { an presenta } \\
\text { naspek }\end{array}$ & & $96,8 \%$ & Positif \\
\hline
\end{tabular}

Berdasarkan tabel 3, dapat diketahui bahwa persentase rata-rata respons siswa terhadap media pembelajaran pohon bangun ruang memiliki nilai lebih besar dari $50 \%$. Persentase respons siswa berdasarkan keseluruhan aspek adalah 96.8\%, sehingga dapat disimpulkan bahwa respons siswa terhadap media pembelajaran pohon bangun ruang yang digunakan bernilai positif. 
Keefektifan media pembelajaran diperoleh dari hasil analisis kemampuan guru dalam mengelola pembelajaran, pengamatan aktivitas siswa, dan tes hasil belajar siswa terhadap media pembelajaran. Hasil analisis kemampuan guru dalam mengelola pembelajaran terhadap media pembelajaran pohon bangun ruang dapat dilihat pada tabel berikut.

Tabel 4. Hasil Analisis Kemampuan Guru dalam Mengelola Pembelajaran

\begin{tabular}{|c|c|c|c|}
\hline No. & Aspek Penilaian & $\begin{array}{l}\text { Rata-Rata } \\
\text { Pert. I-II }\end{array}$ & Ket. \\
\hline \multicolumn{4}{|c|}{ I. Kegiatan Pembelajaran } \\
\hline \multicolumn{4}{|c|}{ A. Kegiatan Awal } \\
\hline 1. & $\begin{array}{l}\text { Menyampaikan apersepsi terhadap materi yang } \\
\text { diajarkan. }\end{array}$ & 3,75 & Sangat baik \\
\hline 2. & $\begin{array}{l}\text { Menyampaikan tujuan pembelajaran dan metode } \\
\text { pembelajaran }\end{array}$ & 4 & Sangat baik \\
\hline & Rata-Rata Aspek IA $=\frac{\text { Total rata-rata pert } I-I I}{\text { Jumlah aspek IA }}$ & 3,87 & Sangat baik \\
\hline \multicolumn{4}{|c|}{ B. Kegiatan Inti } \\
\hline 1. & $\begin{array}{l}\text { Memperkenalkan media pembelajaran kepada siswa } \\
\text { dan mengajukan masalah terkait media } \\
\text { pembelajaran }\end{array}$ & 4 & Sangat baik \\
\hline 2. & $\begin{array}{l}\text { Mengarahkan siswa untuk membentuk kelompok } \\
\text { belajar }\end{array}$ & 4 & Sangat baik \\
\hline 3. & $\begin{array}{l}\text { Memotivasi siswa untuk mengumpulkan informasi } \\
\text { dari masalah tersebut }\end{array}$ & 3,75 & Sangat baik \\
\hline 4. & $\begin{array}{l}\text { Membimbing siswa dalam menyiapkan laporan } \\
\text { hasil pemecahan masalah }\end{array}$ & 3,5 & Sangat baik \\
\hline 5. & $\begin{array}{l}\text { Membimbing siswa untuk melakukan presentasi } \\
\text { laporan hasil pemecahan masalah di depan kelas }\end{array}$ & 3,75 & Sangat baik \\
\hline 6. & $\begin{array}{l}\text { Meluruskan dan memberi penguatan terhadap } \\
\text { jawaban yang berkembang dalam diskusi }\end{array}$ & 3,75 & Sangat baik \\
\hline & Rata-Rata Aspek IB $=\frac{\text { Total rata-rata pert I-II }}{\text { Jumlah aspek IB }}$ & 3,79 & Sangat baik \\
\hline \multicolumn{4}{|c|}{ C. Kegiatan Akhir } \\
\hline 1. & Memberikan tugas terkait media pembelajaran & 4 & Sangat baik \\
\hline 2. & $\begin{array}{l}\text { Menyampaikan materi yang akan dipelajari pada } \\
\text { pertemuan berikutnya }\end{array}$ & 4 & Sangat baik \\
\hline & Rata-Rata Aspek IC $=\frac{\text { Total rata-rata pert } I-I I}{\text { Jumlah aspek IC }}$ & 4 & Sangat baik \\
\hline \multicolumn{4}{|c|}{$\begin{array}{ll}\text { II. Suasana Kelas } \\
\end{array}$} \\
\hline 1. & $\begin{array}{l}\text { Siswa antusias menggunakan media dalam proses } \\
\text { pembelajaran }\end{array}$ & 4 & Sangat baik \\
\hline 2. & $\begin{array}{l}\text { Guru antusias menggunakan media dalam proses } \\
\text { pembelajaran }\end{array}$ & 4 & Sangat baik \\
\hline 3. & Kegiatan sesuai skenario pada RPP & 4 & Sangat baik \\
\hline & Rata-Rata Aspek ID $=\frac{\text { Total rata-rata pertI }-I I}{\text { Jumlah aspek ID }}$ & 4 & Sangat baik \\
\hline Rata & Rata Seluruh Aspek $=\frac{\text { Total } \text { rata }- \text { rata seluruh aspek }}{\text { Jumlah seluruh aspek }}$ & 3.91 & Sangat baik \\
\hline
\end{tabular}


Hasil analisis data kemampuan guru dalam mengelola pembelajaran matematika dengan menggunakan media pembelajaran pohon bangun ruang pada uji coba diperoleh rata-rata skor kemampuan guru dalam mengelola pembelajaran matematika adalah 3,91 berada pada kriteria $3,5 \leq K G<4,5$, artinya kemampuan guru dalam mengelola pembelajaran matematika dengan menggunakan media pembelajaran pohon bangun ruang berada pada kategori sangat baik.

Hasil analisis aktivitas siswa terhadap media pembelajaran pohon bangun ruang dapat dilihat pada tabel berikut.

Tabel 5. Hasil Analisis Aktivitas Siswa

\begin{tabular}{llcc}
\hline \multirow{2}{*}{ No. } & \multicolumn{2}{c}{ Aspek Pengamatan Aktivitas Siswa } & \multicolumn{2}{c}{$\begin{array}{c}\text { Persentase Aktivitas Siswa pada } \\
\text { Pertemuan ke- }\end{array}$} \\
\cline { 3 - 4 } & \multicolumn{1}{|c}{$\mathbf{1}$} & $85,4 \%$ \\
\hline 1 & $\begin{array}{l}\text { Siswa membaca dan mencermati konteks } \\
\text { masalah yang ada dalam modul }\end{array}$ & $89,5 \%$ & $85,4 \%$ \\
\hline 2 & $\begin{array}{l}\text { Siswa membentuk kelompok untuk } \\
\text { menyelesaikan masalah yang ada dalam } \\
\text { modul }\end{array}$ & $93,7 \%$ & $77 \%$ \\
\hline 3 & $\begin{array}{l}\text { Siswa mendiskusikan jawaban dari } \\
\text { permasalahan yang ada bersama dengan } \\
\text { teman kelompoknya }\end{array}$ & $75 \%$ & $70,8 \%$ \\
\hline 4 & $\begin{array}{l}\text { Siswa mempresentasikan/menanggapi hasil } \\
\text { jawaban diskusi kelompok lain }\end{array}$ & $79,1 \%$ & $89,5 \%$ \\
\hline 5 & $\begin{array}{l}\text { Siswa menarik kesimpulan atau rangkuman } \\
\text { dari materi yang telah dipelajari }\end{array}$ & $93,7 \%$ & $81,6 \%$ \\
\hline \multicolumn{1}{c}{ Persentase Rata-Rata } \\
\hline
\end{tabular}

Berdasarkan tabel 5, diperoleh hasil analisis aktivitas siswa dengan persentase rata-rata semua pertemuan sebesar $96,8 \%$ yang berada pada interval persentase $80 \leq P \leq$ 100, artinya aktivitas siswa dalam proses pembelajaran sangat baik. Jadi, dapat disimpulkan bahwa aktivitas siswa dalam proses pembelajaran dapat dikatakan efektif.

Hasil analisis skor tes hasil belajar siswa setelah menggunakan media pembelajaran pohon bangun ruang dapat dilihat pada tabel berikut.

Tabel 6. Distribusi Frekuensi dan Persentase Skor Prestasi Hasil Belajar Matematika Siswa Kelas VIII A MTs Ash-Shalihin pada Tes Hasil Belajar

\begin{tabular}{cccc}
\hline Skor & Kategori & Frekuensi & Persentase \\
\hline $0-39$ & Sangat rendah & 0 & $0 \%$ \\
\hline $40-59$ & Rendah & 1 & $4,5 \%$ \\
\hline $60-74$ & Sedang & 2 & $9 \%$ \\
\hline $75-90$ & Tinggi & 14 & $63,6 \%$ \\
\hline $91-100$ & Sangat tinggi & 5 & $22,7 \%$ \\
\hline
\end{tabular}

Berdasarkan tabel 6, diketahui bahwa tidak terdapat siswa yang berada pada kategori sangat rendah. Siswa yang berada pada kategori rendah sebesar 4,5\%. Siswa 
yang berada pada kategori sedang ada 9\%, siswa yang termasuk kategori tinggi sebesar $63,6 \%$, dan siswa yang termasuk kategori sangat tinggi adalah 22,7\%. Dengan demikian, dapat disimpulkan bahwa skor rata-rata hasil belajar matematika seluruhnya berada dalam kategori tinggi.

Tabel 7. Deskripsi Ketuntasan Pencapaian Tes Hasil Belajar Kelas VIII A MTs AshShalihin

\begin{tabular}{cccc}
\hline Skor & Kategori & Frekuensi & Persentase (\%) \\
\hline$<75$ & Tidak tuntas & 3 & $13,6 \%$ \\
\hline$\geq 75$ & Tuntas & 19 & $86,3 \%$ \\
\hline
\end{tabular}

Berdasarkan tabel 7, dapat diketahui bahwa persentase ketuntasan belajar siswa kelas VIII A MTs Ash-Shalihiin sebesar 86,3\% dan 13,6\% yang belum tuntas dalam tes hasil belajar dikarenakan beberapa alasan. Salah satu alasannya adalah siswa terlalu lamban dalam menulis sehingga waktu yang diberikan dianggap kurang. Hal ini menunjukkan bahwa ketuntasan belajar klasikal siswa berada dalam kategori tinggi. Oleh karena itu, dapat disimpulkan bahwa media pembelajaran yang dikembangkan efektif digunakan dalam proses pembelajaran.

\subsection{Pembahasan}

Tahap pertama yang dilakukan adalah analisis (analysis). Kegiatan utama pada tahap ini adalah mengidentifikasi masalah, mengidentifikasi sumber masalah, dan menentukan solusi dari permasalahan yang dihadapi oleh guru dan siswa dalam pembelajaran matematika. Adapun masalah yang ditemukan yakni masih banyak siswa yang tidak terlibat aktif dalam pembelajaran. Siswa masih bingung membedakan sifatsifat dari bangun ruang sisi datar, seperti jumlah rusuk, sisi, titik sudut, diagonal bidang, dan diagonal ruang pada kubus, balok, prisma, dan limas. Siswa juga kurang terlibat aktif dalam pembelajaran yang dilakukan karena kurangnya daya tarik saat proses pembelajaran.

Sumber masalahnya ternyata berada pada media yang digunakan saat pembelajaran matematika. Media pembelajaran hanya berupa buku paket dan alat peraga. Alat peraga yang digunakan yakni kerangka kubus dan balok yang hanya terbuat dari karton manila. Penggunaan media pembelajaran tersebut masih terbatas karena hanya guru yang memiliki buku paket dan kerangka kubus dan balok sebagai penunjang proses pembelajaran. Media pembelajaran tersebut kurang memberikan waktu yang cukup kepada siswa untuk memahami materi-materi yang dipresentasikan, menghubungkannya dengan pengetahuan sebelumnya, dan mengaplikasikannya ke dunia nyata. Apalagi jika hal ini dikaitkan dengan materi bangun ruang sisi datar yang sifatnya abstrak.

Oleh karena itu, solusi yang tepat untuk mengatasi permasalahan tersebut yakni mengembangkan media pembelajaran yang lebih menarik. Media pembelajaran yang akan dikembangkan berupa alat peraga pohon bangun ruang. Peneliti memilih media pembelajaran berupa alat peraga, karena kondisi ruang kelas yang tidak memungkinkan untuk menggunakan media pembelajaran berbantuan komputer. Media pembelajaran pohon bangun ruang ini merupakan pengembangan dari media sebelumnya yang akan dimodifikasi semenarik mungkin. Pemilihan media pembelajaran pada penelitian ini sesuai dengan kebutuhan materi serta siswa. Pemilihan media merupakan salah satu faktor yang menunjang tercapainya tujuan pembelajaran. 
Pemilihan media pembelajaran yang didukung oleh hasil penelitian yang relevan terkait media pembelajaran pada materi bangun ruang sisi datar mendapat penilaian menarik dan layak dijadikan sebagai media pembelajaran untuk SMP kelas VIII pada materi bangun ruang sisi datar. Pelaksanaan uji coba penelitian tersebut melibatkan 22 siswa. Siswa diarahkan untuk memperhatikan penjelasan bahan ajar berupa media adobe flash yang dikembangkan. Meskipun media yang dikembangkan sudah cukup bagus, namun proses pembelajarannya masih lebih berpusat kepada guru. Kebebasan interaksi antarsiswa masih kurang dan masih sulit mengaplikasikan materi bangun ruang sisi datar kepada situasi di kehidupan nyata. Hal tersebut terjadi karena media adobe flash yang dikembangkan hanya bisa digunakan dengan menggunakan komputer sehingga memiliki keterbatasan bagi siswa untuk mengakses pengetahuan lebih dalam lagi. Kebosanan dapat saja terjadi karena yang bertindak sebagai fasilitator dan pembimbing media adobe flash tersebut hanya guru (Sari, 2018: 76).

Berdasarkan hal tersebut, maka peneliti mengambil inisiatif untuk mengubah media pembelajaran ke dalam bentuk yang lebih nyata serta mengubah teknis penggunaan media tersebut. Peneliti membuat media pembelajaran berupa alat peraga yang mampu digunakan oleh siswa itu sendiri. Media tersebut dibuat agar proses siswa dalam menyelesaikan permasalahan yang diberikan oleh guru dilakukan dengan mandiri, bebas, dan sesuai dengan pola pikir mereka.

Pengembangan media didasari atas tujuan untuk menghasilkan media pembelajaran berupa alat peraga dengan kelayakan yang baik, khususnya pada materi bangun ruang sisi datar. Setiap materi ajar memiliki karakteristik mulai dari tingkat kesukarannya hingga karakteristik lain yang memerlukan penanganan khusus dalam pembelajaran agar pesan pembelajaran dapat tersampaikan kepada siswa. Materi bangun ruang sisi datar sifatnya abstrak dengan banyak komponen-komponen yang harus dikuasai siswa.

Pemberian pengalaman belajar yang hanya bersifat verbal dapat membuat siswa kesulitan memahami materi ajar apalagi jika hanya menggunakan media seadanya seperti buku paket yang jumlahnya terbatas dan tidak semua siswa memilikinya. Penampilan gambar mengenai bangun ruang sisi datar di papan tulis maupun di komputer dapat membantu siswa dalam memahami bahan ajar. Hal tersebut dapat dikemas dengan lebih menarik jika ditampilkan pada situasi nyata dan berwarna dengan informasi mengenai bangun ruang sisi datar (Sanaky, 2013: 26).

Hal tersebut didukung oleh pengalaman Dale dalam Salim \& Tiawa (2014: 80) yang mengatakan bahwa semakin banyak indera yang berperan, maka bahan ajar dapat lebih mudah dipahami daripada keterampilan yang diperoleh lewat penyampaian pesan pembelajaran secara biasa. Dengan menggunakan media pembelajaran berupa alat peraga, memungkinkan banyak indera yang berperan seperti visual dan auditori. Keterampilan siswa juga diperlukan dalam pelaksanaan media, sehingga memungkinkan adanya partisipasi aktif dari siswa. Selain itu, memungkinkan pula penerapan konsep-konsep dalam situasi dan peran yang sebenarnya di masyarakat. Keterampilan yang dipelajari melalui alat peraga jauh lebih mudah diterapkan di kehidupan nyata.

Kegiatan pada tahap design (perancangan) yakni merancang skenario pembelajaran, merancang desain awal media pembelajaran, dan merancang evaluasi hasil belajar. Adapun skenario pembelajaran saat mengujicobakan media pembelajaran yang telah dikembangkan yakni termuat di dalam Rencana Pelaksanaan Pembelajaran (RPP). Model pembelajaran yang digunakan saat mengujicobakan media pembelajaran 
pohon bangun ruang adalah model pembelajaran berbasis masalah. Model pembelajaran berbasis masalah dipilih karena dalam tahapannya tidak hanya berpusat kepada guru, akan tetapi melibatkan siswa secara penuh ke dalam proses pembalajaran. Kemudian, pemilihan kompetensi dasar dan indikator pembelajaran didasari atas pemasalahan yang diperoleh dari hasil observasi dan wawancara di sekolah yakni sulit membedakan sifat-sifat pada kubus, balok, prisma, dan limas. Adapun penyusunan tes hasil belajar dilakukan dengan terlebih dahulu menyusun kisi-kisi tes yang sesuai dengan kebutuhan siswa dan indikator pencapaian kompetensi.

Tahap selanjutnya adalah development (pengembangan), kegiatan di tahap ini adalah melaksanakan pembuatan media pembelajaran pohon bangun ruang dan melakukan revisi serta validasi media oleh ahli media dan materi. Pembuatan media pembelajaran pohon bangun ruang dilakukan secara manual sehingga memerlukan waktu selama dua hari. Media pembelajaran yang dikembangkan dapat digunakan dalam proses pembelajaran setelah melalui tahap validasi. Validasi dilakukan untuk mengetahui tingkat kelayakan media pembelajaran untuk diterapkan di kelas. Setelah media pembelajaran pohon bangun ruang diproduksi, langkah selanjutnya adalah divalidasi untuk mengetahui tingkat kelayakan media tersebut. Penilaian meliputi aspek tampilan dan aspek bahasa. Setelah melalui tahap pengembangan, maka akan diperoleh prototype I. Prototype I direvisi berdasarkan masukan dari validator ahli serta dosen pembimbing, sehingga diperoleh prototype II dan prototype III.

Nilai rata-rata kevalidan media prototype III adalah 3,40 yang berada pada kategori valid. Nilai rata-rata kevalidan media prototype II adalah 3,40 yang berada pada kategori valid yakni $2,5 \leq M \leq 3,5$. Berdasarkan hasil penilaian dari validator, media pembelajaran pohon bangun ruang layak menjadi produk akhir untuk digunakan dalam proses pembelajaran.

Tahap implementasi (implementation) dilaksanakan pada tanggal 16 Juli 2019 dan 17 Juli 2019 yang dikhususkan pada kelas VIII A MTs Ash-Shalihin yang beralamatkan Jl. Mustafa Dg Bunga, Kel. Romang Polong, Kec. Somba Opu, Kab. Gowa. Jumlah siswa 26 orang namun pada saat proses implementasi hari pertama hanya 24 siswa yang hadir, sedangkan hari kedua hanya 22 siswa yang hadir. Pada pertemuan pertama, peneliti bertindak sebagai observer, sedangkan yang melaksanakan proses pembelajaran adalah guru. Pada pertemuan kedua, peneliti yang melaksanakan proses pembelajaran. Dengan demikian, guru sebagai pelaksana pembelajaran dan pembimbing penggunaan media dapat memberikan penilaian yang akurat mengenai kepraktisan media pembelajaran yang dikembangkan.

Tahap evaluasi (evaluation) dilakukan untuk menguji kepraktisan dan keefektifan media pembelajaran pohon bangun ruang. Kepraktisan media pembelajaran dapat diketahui dari angket respons guru dan angket respons siswa. Angket respons guru dan angket respons siswa yang telah dianalisis menunjukkan respons yang positif terhadap media pembelajaran yang digunakan. Hasil analisis data dari komponenkomponen kepraktisan tersebut adalah persentase rata-rata untuk respons guru yakni $97,7 \%$ dan persentase rata-rata respons siswa yakni 96,8\%. Persentase rata-rata respons guru dan siswa terhadap media pembelajaran pohon bangun ruang memiliki nilai lebih besar dari $50 \%$. Dengan demikian, media pembelajaran yang dikembangkan memenuhi kriteria praktis.

Keefektifan media pembelajaran dapat diketahui dari kemampuan guru dalam mengelola pembelajaran, aktivitas siswa, dan tes hasil belajar. Berdasarkan hasil analisis data, rata-rata skor kemampuan guru dalam mengelola pembelajaran 
matematika dengan menggunakan media pembelajaran pohon bangun ruang pada uji coba adalah 3,91 berada pada kriteria $3,5 \leq K G<4,5$ yang artinya kemampuan guru dalam mengelola pembelajaran matematika dengan menggunakan media pembelajaran pohon bangun ruang berada pada kategori sangat baik. Hasil analisis persentase aktivitas siswa dalam proses pembelajaran pada uji coba diperoleh $96,8 \%$ yang berada pada interval presentase $80 \leq P \leq 100$, artinya aktivitas siswa dalam proses pembelajaran sangat baik. Hasil analisis tes hasil belajar menunjukkan bahwa dari 22 siswa yang mengikuti tes hasil belajar, tidak terdapat siswa yang berada pada kategori sangat rendah. Siswa yang berada pada kategori rendah sekitar 4,5\%. Siswa yang berada pada kategori sedang ada 9\% sedangkan siswa yang termasuk kategori tinggi sekitar $63,6 \%$ dan yang termasuk kategori sangat tinggi adalah 22,7\%. Berdasarkan skor tes hasil belajar, diketahui bahwa persentase ketuntasan belajar kelas VIII A MTs AshShalihiin sebesar $86,3 \%$ dan $13,6 \%$ yang belum tuntas dalam tes hasil belajar dikarenakan beberapa alasan. Salah satu alasannya adalah mereka terlalu lamban dalam menulis sehingga waktu yang diberikan dianggap kurang. Hal ini menunjukkan bahwa ketuntasan belajar klasikal siswa berada dalam kategori tinggi.

Dalam pelaksanaan penelitian ditemukan beberapa kendala terutama dalam kegiatan uji coba media pembelajaran pohon bangun ruang. Siswa terkadang masih sulit mengubah kebiasaan belajar yaitu hanya duduk menyaksikan guru menerangkan. Siswa merasa kesulitan karena harus aktif dalam pembelajaran. Siswa harus menyelesaikan masalah dalam kegiatan belajar yang diberikan secara berkelompok. Hal tersebut tidak biasa mereka lakukan sehingga pada pertemuan awal uji coba peneliti merasa kewalahan dalam mengarahkan siswa. Selain itu, siswa terkadang bersifat acuh tak acuh jika peneliti memberikan instruksi sehingga persiapan sebelum pembelajaran berlangsung lama dan menyita banyak waktu.

\section{Simpulan}

Media pembelajaran berupa alat peraga POBAR (Pohon Bangun Ruang) dikembangkan menggunakan model pengembangan ADDIE untuk menghasilkan media pembelajaran matematika pada materi bangun ruang sisi datar yang valid, praktis, dan efektif. Kriteria valid diketahui berdasarkan hasil validasi para ahli. Hasil validasi aspek media pembelajaran pohon bangun ruang pada materi bangun ruang sisi datar adalah 3,40 . Hal ini berarti hasil penilaian valid dengan kategori berada pada interval $2,5 \leq$ $M \leq 3,5$. Kriteria praktis diketahui berdasarkan analisis data respons guru dan analisis data respons siswa terhadap media pembelajaran yang dikembangkan. Hasil persentase rata-rata untuk respons guru yakni $97,7 \%$ dan persentase rata-rata respons siswa yakni $96,8 \%$. Persentase rata-rata respons guru dan siswa terhadap media pembelajaran pohon bangun ruang memiliki nilai lebih besar dari 50\%. Dengan demikian, media pembelajaran yang dikembangkan memenuhi kriteria praktis. Kriteria efektif diketahui berdasarkan hasil kemampuan guru mengelola pembelajaran, hasil aktivitas siswa, dan hasil tes hasil belajar siswa. Hasil analisis rata-rata skor kemampuan guru adalah 3,91 berada pada kriteria 3,5 $\leq K G<4,5$, aktivitas siswa dalam kategori sangat baik yakni $96,8 \%$ dengan interval persentase $80 \leq P \leq 100$, dan tes hasil belajar berada dalam kategori tinggi dengan persentase ketuntasan belajar keseluruhan siswa sebesar 86,3\%. 


\section{Daftar Pustaka}

Arikunto, S. (1996). Prosedur Penelitian. Jakarta: Rineka Cipta.

Arsyad, A. (2015). Media Pembelajaran (XVII). Jakarta: Rajawali Press.

Gunantara, G., Suarjana, M., \& Riastini, P. N. (2014). Penerapan Model Pembelajaran Problem Based Learning untuk Meningkatkan Kemampuan Pemecahan Masalah Matematika Siswa Kelas V. Jurnal Mimbar PGSD, 2(1). Retrieved from https://ejournal.undiksha.ac.id/index.php/JJPGSD/article/view/2058

Kiswanto, K., Rahman, U., \& Sulasteri, S. (2015). Deskripsi Pemahaman Konsep Materi Geometri Ditinjau dari Kepribadian Sensing dan Intuition pada Siswa Kelas IX SMPN 33 Makassar. MaPan: Jurnal Matematika dan Pembelajaran, 3(1), 41-58. Retrieved from http://journal.uin-alauddin.ac.id/index.php/Mapan /article/view/2742

Masykur, R., \& Syazali, M. (2017). Pengembangan Media Pembelajaran Matematika dengan Macromedia Flash. Jurnal Pendidikan Matematika, 8(2), 177-186. Retrieved from http://ejournal.radenintan.ac.id/index.php/al-jabar/article/view/ 2014

Muzakkir. (2012). Microteaching Teori dan Aplikasinya dalam Pembelajaran. Makassar: Alauddin University Press.

Nurfadillah. (2017). Pengembangan Media Pembelajaran Permainan Ular Tangga pada Materi Sistem Saraf di Kelas XI MA Madani Alauddin Paopao. UIN Alauddin Makassar.

Pratiwi, M. C., Riyana, C., \& Dewi, L. (2013). Pengembangan Media Pembelajaran Augmented Reality Pocket Book (ARPOOK) pada Materi Bangun Ruang Sisi Datar. Jurnal Teknologi Pendidikan, 1-14. Retrieved from https://www. academia.edu/35564821/PENGEMBANGAN_MEDIA_PEMBELAJARAN_A UGMENTED_REALITY_POCKET_BOOK_PADA_MATERI_BANGUN_RU ANG_SISI_DATAR_Studi_Pengembangan_Media_Pembelajaran_Berdasarkan _Metode_Design_and_Development?auto=download

Puji, K. M., Gulö, F., \& Ibrahim, A. R. (2014). Pengembangan Multimedia Interaktif untuk Pembelajaran Bentuk Molekul di SMA. Jurnal Penelitian Pendidikan Kimia, 1(1), 59-65. Retrieved from https://ejournal.unsri.ac.id/index.php /jurpenkim/article/view/2385

Salim, K., \& Tiawa, D. H. (2014). Development of Media-Based Learning Animation for Mathematics Courses in Electrical Engineering, University Riau Kepulauan. International Journal of Advanced Research in Computer and Communication Engineering, 3(10), 8332-8336. Retrieved from https://ijarcce.com/wpcontent/uploads/2014/10/IJARCCE4K-a-kalbin-Development-of-Media-BasedLearning-Animation-for-Mathematics-Courses-in-Electrical-Engineering-Unive rsity-Riau-Kepulauan.pdf

Sanaky, H. A. (2013). Media Pembelajaran Interaktif-Inovatif. Yogyakarta: Kaukaba Dipantara.

Sari, A. P., \& Setiawan, A. (2018). The Development of Internet-Based Economic Learning Media using Moodle Approach. International Journal of Active Learning, 3(2), 100-109. Retrieved from https://journal.unnes.ac.id/nju/index .php/ijal/article/download/13449/7458

Sari, R. S. P. (2018). Pengembangan Bahan Ajar Matematika pada Materi Bangun Ruang Sisi Datar Menggunakan Software Microsoft Adobe Flash untuk Kelas VIII SMP. UIN Raden Intan Lampung. 
Suharjana, A. (2008). Mengenal Bangun Ruang dan Sifat-Sifatnya. Yogyakarta: Pusat Pengembangan dan Pemberdayaan Pendidik dan Tenaga Kependidikan Matematika.

Trianto. (2007). Model Pembelajaran Terpadu dalam Teori dan Praktek. Jakarta: Prestasi Pustaka.

Zaerani, S., Mardhiah, \& Suharti. (2017). Pengaruh Penguasaan Konsep Teorema Pythagoras terhadap Kemampuan Menyelesaikan Soal-Soal Bangun Ruang Sisi Datar pada Siswa Kelas VIII MTS Negeri Balang-Balang. MaPan: Jurnal Matematika dan Pembelajaran, 5(2), 279-292. Retrieved from http://journal .uin-alauddin.ac.id/index.php/Mapan/article/view/3616/pdf 